\title{
NEW TRENDS OF THE CIVIL JUSTICE IN HUNGARY
}

\author{
Viktória Harsági \\ Pázmány Péter Catholic University, Faculty of Law
}

\begin{abstract}
The article provides an overview on the most important innovations of the new Hungarian Code of Civil Procedure. It presents a renewed system of allocation of cases, the split structure of the procedural phases, the modifications in connection of the representation, the new regulation on the illegaly obtained evidence, the solutions for incapacity to prove, the remedies and collective redress. Finally, the manuscript goes on with the question of electronization and try to evaluate the modest practical experience of these innovations so far.
\end{abstract}

Key words: civil procedure, new Code of Civil Procedure, litigious proceedings, Hungary.

\section{INTRODUCTION}

The old Hungarian Code of Civil Procedure (Act III of 1952), which has been modified many times since its entry into force, did not follow a uniform concept. After the political transformation, the Hungarian Code of Civil Procedure struggled with the problem of "belonging" and "finding its proper place". In this period of its development one may experience some kind of return to GermanAustrian roots as well as some independence. One part of the modifications was triggered off by international conventions and European Union law. The main regulatory objectives defined by the Draft Bill on the new Code of Civil Procedure included the systemic realization of the effectiveness of court proceedings, diverting claims away from court proceedings (mainly to mediation), establishing procedural rules promoting agreement between the parties, the introduction of a split system of procedural phases, the creation of procedural rules ensuring the concentration of proceedings, the prescription of mandatory legal representation in proceedings commenced before the courts of justice as a guarantee of the professional conduct of proceedings, the creation of domestic rules of collective redress and enhancing the role of reasonable electronization. The new HCCP has introduced significant modifications concerning the rules relating to legal representation, it has afforded an enhanced role to statements made during the preparatory phase, and it has laid down stricter requirements concerning the parties' legal statements. The court has been granted extensive powers to clarify the legal dispute, and the demonstration of expert evidence has been provided with a new basis. There have been significant changes in the rules of the appeals process, while with regard to review a system based on a value limit has been introduced.

\section{CASE ALLOCATION}

The new Code of Civil Procedure (new HCCP - Act CXXX of 2016 entered into force on 1 January 2018) has not changed the system of two levels of first instance courts. Cases are tried at first instance 
by the district courts and the courts of justice. In civil cases local courts had general first-instance jurisdiction before the new Act. From 2018 the new regulation defines courts of justice as the courts having general jurisdiction and also prescribes mandatory representation by counsel before them. By doing so, the regulation basically returns to the traditions of 1911. It introduces uniform procedural rules ${ }^{1}$ (it no longer contains the rules of the former HCCP pertaining to small claims, or the rules relating to matters of special importance, which classified cases based on the value of the claim. The uniform system of procedural rules introduced by the new HCCP is modelled for courts of justice and even in cases initiated before the district courts deviation from these rules is permitted only if the party involved is not legally represented.

Cases falling within the first-instance jurisdiction of the courts of justice can be appealed to the courts of appeal. Review petitions are heard by the Curia. Moreover, it ensures the uniformity of judicial practice.

The purpose of effective case management is intended to be served by the distribution of cases between the two first instance courts (courts of justice and district courts), which takes place so that cases of a more specialized character or of greater complexity and cases involving substantial claims start at a higher level (before the courts of justice). The jurisdiction of district courts extends to a) property cases where the value of the claim does not exceed thirty million forints or where the value of the claim based on property rights cannot be determined (except for actions relating to copyright, neighbouring rights and industrial property rights, actions for general damages or compensation for pain and suffering related to the exercise of official authority, actions launched in the public interest, actions concerning the formation and lawful operation of a legal person, disputes between legal persons and their current or former members, and disputes between current or former members arising from their membership relations), $b$ ) actions related to personal status, $c$ ) enforcement actions. [Section 20 new HCCP].

The new Code of Civil Procedure has not essentially changed the rules relating to jurisdiction, but contains some novelties with regard to consumers (it has introduced rules of exclusive jurisdiction that serve the interests of the weaker party).

\section{PREPARATION}

The new HCCP reintroduced the split system of procedural phases (which used to be applied in the Code of Civil Procedure of Plósz of 1911). According to the explanatory memorandum attached to the Draft Bill, the draft proposal aims to set up a procedural order that will render the course of the proceedings more predictable for the parties, because the split system of procedural phases makes clear the function and duration of the specific procedural phases, thereby establishing unambiguous frames for the performance, restriction or preclusion of specific procedural acts, which will promote not only the effectiveness of proceedings, but also their predictability. First instance proceedings are divided into two stages: the preparatory phase and the merits phase. This model places great emphasis on the preparatory phase. This system provides possibility to concentrate the definition

1 VARGA, I. Identification of Civil Procedure Regulatory Needs with a Comparative View. In ELTE Law Journal, No. 6 (2014), p. 139 - 140.; VARGA, I. Perrendi szabályozási igények azonosítása jogösszehasonlító kitekintéssel. In VARGA, I. (ed.): Codificatio processualis civilis. Studia in Honorem Németh János II. Budapest : ELTE Eötvös Kiadó, 2013, p. 492., $496-498$. 
of the content and frames of the legal dispute in the preparatory phase (motions for evidence and means of evidence become fixed). However - according to the explanatory memorandum - the preparatory phase does not lack flexibility: the specific steps involved in this phase are decided by the court, which enables the court to decide on the method and course of preparation in line with the particular characteristics of the specific case. ${ }^{2}$

The new Act applies a wide range of preclusions. For example, after the closing of the preparatory phase, as a general rule, it is not possible to modify the claim or defence, and the submission of further evidence and motions is precluded. The aim of the restriction - besides preventing the protraction of proceedings - is to also enable both the court and the opposing party at some point to regard the frames and content of the legal dispute finally fixed and to ensure that following this nothing but the evidence taking procedure and the decision on the merits should take place based on the fixed allegations. The modification of the claim may be permitted following the dividing line only if such modification is related to a cause that cannot be attributed to the fault of the party concerned.

Concerning the new regulation it is not yet possible to account of the practical experiences as not even three months have passed since the entry into force of the code, but a change may also be expected in the role of the hearing on the merits phase: the aim is to conduct the evidence taking concerning the legal dispute defined in the preparatory phase, which - as a result of the preparation - will become a lot more expedient and therefore one may expect an earlier decision on the merits of the case.

\section{$4 \quad$ FIRST INSTANCE LEVEL}

The new Code of Civil Procedure models uniform rules of procedure as a system of professional procedural rules, in relation to which it precisely determines the statutory situations - always along the lines of groups of persons or interests requiring protection - where deviation in the direction of more simple procedure is necessary and possible. ${ }^{3}$ The new HCCP introduced a split system of procedural phases, which renders the course of the proceedings more plannable and predictable.

According to the expectations of the legislator, the professionalism of the parties' procedural acts may significantly contribute to effective claim enforcement and legal protection as well as defence against them, moreover, the resolution of lawsuits within a reasonable time. The detailed and elaborated content of the most important submissions, e.g. that of the statement of claim and the defence, which are to be submitted in written form obligatorily, serves both the proper and expedient preparation of the lawsuit and the conversion of submissions into standard forms, which provides help for the party acting without a legal representative and also facilitates electronic communication. Unfortunately, the first experiences do not corroborate these expectations. In the first months of the application of the new Code, an extreme number of statements of claims have been dismissed, which according to the accounts of lawyers has perceivably reduced the willingness of potential claimants to commence litigation.

2 Cpr. KÖBLÖS, A. Hungary - Towards More Efficient Preparatory Proceeding. In ERVO, L., NYLUND, A. Current Trends in Preparatory Proceedings. Cham: Springer, 2016, p. 185 - 205.

3 KARCZUB, E. al. Általános rendelkezések és alapelvek. In VARGA, I., ÉLESS, T. Szakértői Javaslat az új polgári perrendtartás kodifikációjára. Budapest: HVG-Orac - Magyar Közlöny Lap- és Könyvkiadó Kft., 2016, p. 798 - 800. 
At the level of district courts (if the party is not legally represented) numerous rules have been introduced to facilitate the enforcement of rights, e.g. the use of standard forms, lesser requirements regarding submissions, and the party is also supported by the judge's substantive measures of conduct a case. According to the explanatory memorandum attached to the Draft Bill, this means a flexible alternative solution in cases of lesser complexity and in cases presupposing the involvement of a weaker party.

Apart from the exigency of providing evidence and the admissibility of illegally obtained means of proof, the most important innovation in the regulation relating to the demonstration of evidence is the reform of expert evidence: private expert opinions are also properly incorporated into the system. The party may supply expert evidence in three ways: by way of a private expert engaged by him, through an expert appointed for him in another proceeding, or via an expert appointed for him in the lawsuit. Private expert evidence - according to the explanatory memorandum attached to the Draft Bill - is expected to put an end to the current practice leading to the protraction of proceedings under which private expert opinions are used not for the main taking of evidence, but with the aim of contesting or challenging the professional competence of the expert appointed by the court.

The appearance of the parties' obligation to assist the court in administering justice as a basic principle is also a novelty in the new HCCP. The definition of the content of obligation to assist the court in administering justice - at least with regard to its limits - may pose a problem at first sight. The obligation to assist the court in administering justice involves the party's enhanced procedural responsibility, which means a supportive and active role. One might suppose that this active role is problematic in respect of the defendant, since active role on the side of the defendant would mean defence, moreover, defence against the relief sought by the claimant. It is important to emphasize that it is not so, the defendant is not obliged to put up a defence: he has self-autonomy, in other words, he is free to decide. ${ }^{4}$

The court's obligation to carry out contributive actions is also a new element, in the centre of which are the change in and the enhanced role of tools for the conduct of the case. In the range of the court's contributive actions, the new code has strengthened the court's powers relating to the conduct of the case. ${ }^{5}$

\section{EXIGENCY OF PROVIDING EVIDENCE (INCAPACITY TO PROVE) - UNLAWFUL EVIDENCE}

The old HCCP (before 2018) contained only a few provisions the violation of which would result in the unlawfulness of evidence. With regard to the use of unlawfully obtained evidence, the HCCP did not formulate generally applicable clauses of the type contained in the Act on Criminal Procedure. Prohibitions were concentrated around the witness statement and expert opinion, but in other areas the lack of general and special prohibitions results in uncertainty concerning such illegalities

\footnotetext{
4 MOLNÁR, T. Az új polgári perrendtartás alapelveinek értékelése, a perjogi kodifikáció hatása a polgári eljárás sajátos alapelveire. In Közjegyzők Közlönye, No. 6 (2017), p. 20.

5 Ibid., p. 23.
} 
arising out of litigation ${ }^{6}$ as e.g. the stealing of documents or obtaining an electronic letter through unauthorised access to the e-mail system.

The new HCCP regulates as a new legal institution the exigency of providing evidence, the admissibility of illicit means of evidence in the lawsuit, and the probative value of evidence from other procedures used in civil proceedings. According to the explanatory memorandum to the Draft Bill, the exigency of providing evidence (incapacity to prove) means a regulatory solution to strikingly information-asymmetric situations, where the adversary of the party having the burden of proof has the relevant evidence in his possession and therefore he is able to make it difficult or impossible to prove the case successfully. The legal consequence of the exigency of providing evidence is: the court establishes the existence of the fact, if the judge has no doubt in this regard. The new HCCP regulates the frames of admissibility of unlawfully obtained means of evidence, but does not lay down an absolute prohibition concerning them. Pursuant to Section 265, the facts in a case shall be proven by the party having an interest in the fact being accepted by the court as the truth (hereinafter "interest to prove"), and the consequences of not proving or unsuccessfully proving such fact shall also be borne by said party. The party is in a situation of exigency of providing evidence, if he substantiates that $a$ ) the data indispensable for his motion to present evidence are in the exclusive possession of the party with opposing interests, and he verifies that he took the necessary measures to obtain such data, $b$ ) it is not possible for him to prove the facts alleged, but the opposing party can be expected to supply evidence to disprove his allegations of fact, or $c$ ) the success of taking evidence was hindered by the party with opposing interests in a culpable manner, and the other party does not substantiate the opposite of those specified in points $a$ ) to $c$ ). If the party is under the exigency of providing evidence, the fact to be proven by the party affected by such exigency may be accepted by the court as the truth, if it does not have any doubt regarding its veracity.

Pursuant to Section 269 of the CCP, a means of proof, or any separable part of it, is unlawful and cannot be used in the action, if (i) it was obtained or produced by violating or threatening a person's right to life and physical integrity, (ii) it was produced by any other unlawful method, (iii) it was obtained in an unlawful manner, or (iv) its submission to the court would violate personality rights. A means of proof shall be considered evidently unlawful if that can be clearly established as a fact on the basis of evidence and data available. The evidently unlawful nature of a means of proof is to be taken into account by the court ex officio, and the parties are to be informed accordingly. If a means of proof is not evidently unlawful, its unlawful nature shall be notified without delay by the party opposing the party submitting the means of proof. A party may only rely on the unlawfulness of a means of proof following the order closing the preparatory phase, if through no fault of his own he became aware of it only later, and he notifies it to the court within fifteen days after having become aware of it. With the exception of the case described in point (i) above, the unlawful means of proof may be taken into account by the court exceptionally and with due regard to the particular nature and extent of the violation, the legal interests affected by the violation, the impact of the unlawful piece of evidence on establishing the facts, the weight of other available pieces of evidence and all other circumstances of the case. If an unlawful means of proof cannot be used and the proving party cannot prove a significant fact in the case in any other way, the court may apply the rules pertaining to the exigency of providing evidence.

6 KENGYEL, M.A. bizonyítás. In PETRIK, F. (ed.): Polgári eljárásjog. Kommentár a gyakorlat számára. Budapest: HVGORAC, 2017, p. A/373. 


\section{REMEDIES}

The HCCP of 1952 transformed the earlier two instance appellate system into a one level system. In its original form, the above-mentioned Act maintained a kind of second instance proceedings characterizing Plósz' Code of Civil Procedure of 1911. After the democratic transformation in 1989 - 90 the first great impetus to the transformation of the Hungarian remedy system was given by a decision of the Constitutional Court, thus the reform really started in 1992 with the re-introduction of the review procedure. In the past decades, most modifications have been concerned with the institution of review and they have been generated by the decisions of the Constitutional Court in several cases.

It is universally valid that one of the main causes of the delay of civil lawsuits is the excessive caseload on courts. One of the means frequently used to resolve this problem is the restriction of legal remedy (filtering the cases). Restricting techniques may vary: ${ }^{7}$ a limit of amount defined by law or, a specific group of cases that constitute the limit and exclude the possibility of resorting to legal remedy.

The Fundamental Law requires a regular appellate procedure. Conceptual questions arise mostly with respect to the permissibility of extraordinary appeals. Within the question of permissibility, it has to be clarified as to what roles the legislature envisages for the higher courts, especially the Curia, in the area of extraordinary appeals, in other words, what weight it wishes to assign to each of them when developing the dual task-totality of individual legal protection and legal uniformity. Within the scope of permissibility, the separation of permissibility from the disputed amount as the only entry condition also requires a fundamental decision in itself. The amount in controversy and the disputed amount do not determine the significance of the case. ${ }^{8}$

The new HCCP endeavoured to render the rules of appeal more effective. In this respect it aims to achieve a double goal: to ensure due prevalence of the right to legal remedy, and at the same time to prevent the regulation from providing opportunity for the protraction of proceedings during the appellate procedures. Therefore, the Code defines the scope of the second instance court's powers of revision, and determines the obligatory content of appeals accordingly, while at the same time it lays it down as a general rule that the second instance court shall adjudicate the appeal without a hearing. The Code also reregulates the circumstances serving as a ground for setting aside a judgment and therefore resulting in the protraction of proceedings. The essence of the new regulation lies in the fact that violations of procedural rules that do not constitute grounds warranting the mandatory setting aside of judgments are to be taken into account by the second instance court only at the request of the appellant and not ex officio.

The new HCCP deals with the effects of the judgments of the European Court of Human Rights in such a way that it leaves the earlier form of reopening cases for revision as well as the main rules almost entirely intact.

According to the explanatory memorandum attached to the Draft Bill, a so-called mixed system has been introduced concerning the rules of review as an extraordinary remedy, under which the right to review has been preserved within the frames of objective conditions excluding its possibility,

7 Cp. KENGYEL, M. Zivilprozessrecht um die Jahrtausendwende. In Zeitschrift für vergleichende Rechtswissen-schaft. Vol. 101, No. 3 (2002), p. 270 - 271.

8 Cpr. VARGA, I. Perrendi szabályozási igények azonosítása jogösszehasonlító kitekintéssel, op. cit., p. 505. 
but in the case of judgments affected by specific grounds for excluding review the Curia may still allow review having regard to law uniformity considerations. In certain property cases the Curia may exceptionally allow review with regard to law uniformity considerations, or where it is justified by the special significance or social importance of the question of law raised.

\section{COLLECTIVE REDRESS}

The experiences of recent years (more serious cases of environmental pollution, consumer protection problems) have urged experts to reconsider the adequacy of current legal regulations concerning collective redress. ${ }^{9}$ The chapter of the new HCCP on collective redress lays down common procedural rules concerning the rules of public interest actions (actio popularis) already existing in Hungary, but so far typically uncoordinated and contained scattered in various separate laws, thereby consolidating them into one bunch of laws. On the other hand, it contains the rules of coordinated actions to be newly introduced, which may serve as a means to enforce aggregated private interests.

The coordinated action intended to be introduced by the new Code of Civil Procedure is of an opt-in system, also having regard to Commission Recommendation 213/396/EU (of 11 June 2013). In a coordinated action the members of the group may be easily identified individually (their identities are known). However, individual claim enforcement does not use the resources of the justice system with proper effectiveness; therefore it is expedient to deal with them in one proceeding. Thereby, e.g. the costs of evidence may be reduced.

Opt-in system - based on foreign experiences - would be suitable for enforcing claims for damages in product liability cases (e.g. actions against pharmaceutical companies), or claims resulting from railway and air accidents, environmental pollution, and industrial disasters. The scope of the regulation introduced by the new HCCP only covers a small part of these actions (enforcement of claims arising from consumer contracts, claims for damages resulting from health injuries in employment actions based on human action or inaction, and directly caused by invisible environmental impacts or property claims for damages). ${ }^{10}$ If it is justified by the extreme complexity or utmost social significance of the coordinated action coming under the jurisdiction of the courts of justice, the single judge may exceptionally order prior to the order concluding the preparatory phase that a panel of three judges shall proceed in the case. Once a case has been referred to a panel of judges, later it is not possible for a single judge to act concerning the case. As opposed to coordinated actions, public interest actions have been referred to the competence of courts of justice by the new HCCP. If it is justified by the special complexity of the public interest action, the single judge may

9 Cpr. HARSÁGI, V. The Need for Further Development of Collective Redress in Hungary. In HARSÁGI, V., RHEE C.H. (ed.): Multi-party Redress Mechanisms in Europe: Squeaking Mice? Cambridge: Intersentia, 2014. p. 171 - 185.; HARSÁGI, V. Deficiencies of collective redress in Hungary and recomendations for codification. In FANKHAUSER, R. et al. (ed.): Das Zivilrecht und seine Durchsetzung. Zürich: Schulthess Juristische Medien AG, 2016, p. 201 - 215 .; HARSÁGI, V. Quo Vadis Collective Redress? Hungarian Aspects. In Festschrift für Professor Nikolaos K. Klamaris Essays in Honour of Professor Nikolaos K. Klamaris. Athens; Thessaloniki: Sakkoulas Publications, 2016, p. 343 - 355 .; HARSÁGI, V. Combining opt-in and opt-out systems? - Expert Proposal for the Hungarian Regulation of Collective Redress. In ELTE Law journal, 2017, available at: http://eltelawjournal.hu/ [q. 20-01-2019].

10 HARSÁGI, V. Kollektív igényérvényesítés - Általános indokolás a kollektív igényérvényesítéshez. In VARGA, I., ÉLESS, T. (ed.): Szakértői Javaslat az új polgári perrendtartás kodifikációjára. Budapest: HVG-Orac - Magyar Közlöny Lap- és Könyvkiadó Kft., 2016, p. $751-754$. 
exceptionally order prior to the order concluding the preparatory phase that a panel comprising three professional judges shall proceed in the case. Cases that have been referred to a panel cannot subsequently be decided by a single judge.

\section{E-JUSTICE}

Information technology offers possibilities by which access to justice may definitely be improved and proceedings without a legal representative may become better available. Let us think of e.g. the introduction of electronic forms and their publication on the internet. Through them a higher level of automatism may be achieved, especially if their actual filling in online is alleviated by supporting programmes. The rationalizing and accelerating potential resulting from the application of modern IT in court proceedings is dependent on the structure of the given proceeding to some extent. It offers more possibilities for proceedings with a simple structure and a rather routine-like course, where the decision-making process is schematic and more standardizable. ${ }^{11}$ It is no accident that in numerous countries - amoung them in Hungary, too - order for payment proceedings and the company registration procedures have been considered to fall within this category. In these fields e-justice functions effectively and adequately. Moreover, in the case of automated proceedings, the geographic location of the processing court is insignificant, as communication takes place through the internet anyway.

Litigious proceedings - in international comparison - are still rather resistant to the effects of e-justice. The eIDAS Directive, reforming the foundations of electronic identification, was adopted by the European Parliament and the Council in the summer of 2014; following this in May 2015 the Hungarian Government adopted Decision No. 1295/2015. (V. 7.) Korm., in which it took the position that with regard to certain tasks of the court and prosecution service connected with the codes of administrative and civil procedure the delay observable concerning the establishing of electronic communication should be eliminated.

\section{CONCLUSION}

There is still relatively modest practical experience relating to the reform discussed in this article. Considering the information gathered during the codification process, the parallel experiences abroad and the internal inconsistencies of the new Code of Civil Procedure, as well as the not always progressing solutions, it is feared that it will not in all respects adequately meets the expectations of the $21^{\text {st }}$ century. The first sign of this has already been manifested in the mass rejection of claims. However, hopefully, based on the experience of the first years, the shortcomings of the law can be corrected and it can be transformed into a well-functioning system. In the next years this may be the task to be done. This could also increase the value of forward-looking development experiments presented in this article.

11 KODEK, G. Der Zivilprozeß und neue Formen der Informationstechnik. In Zeitschrift für Zivilprozeß, No. 4, 2002, p. 481 . 


\section{Bibliography:}

HARSÁGI, V. Combining opt-in and opt-out systems? - Expert Proposal for the Hungarian Regulation of Collective Redress. In ELTE Law journal, 2017, available at: http://eltelawjournal.hu/ [q. 20-01-2019].

HARSÁGI, V. Deficiencies of collective redress in Hungary and recomendations for codification. In FANKHAUSER, R. et al. (ed.): Das Zivilrecht und seine Durchsetzung. Zürich: Schulthess Juristische Medien AG, 2016.

HARSÁGI, V. Kollektív igényérvényesítés - Általános indokolás a kollektív igényérvényesítéshez. In VARGA, I., ÉLESS, T. (ed.): Szakértői Javaslat az új polgári perrendtartás kodifikációjára. Budapest: HVG-Orac - Magyar Közlöny Lap- és Könyvkiadó Kft., 2016.

HARSÁGI, V. Quo Vadis Collective Redress? Hungarian Aspects. In Festschrift für Professor Nikolaos K. Klamaris Essays in Honour of Professor Nikolaos K. Klamaris. Athens; Thessaloniki: Sakkoulas Publications, 2016.

HARSÁGI, V. The Need for Further Development of Collective Redress in Hungary. In HARSÁGI, V., RHEE C.H. (ed.): Multi-party Redress Mechanisms in Europe: Squeaking Mice? Cambridge: Intersentia, 2014.

KARCZUB, E. et al. Általános rendelkezések és alapelvek. In VARGA, I., ÉLESS, T. Szakértői Javaslat az új polgári perrendtartás kodifikációjára. Budapest: HVG-Orac - Magyar Közlöny Lap- és Könyvkiadó Kft., 2016.

KENGYEL, M.A. bizonyítás. In PETRIK, F. (ed.): Polgári eljárásjog. Kommentár a gyakorlat számára. Budapest: HVG-ORAC, 201711.

KENGYEL, M. Zivilprozessrecht um die Jahrtausendwende. In Zeitschrift für vergleichende Rechtswissen-schaft. Vol. 101, No. 3 (2002).

KODEK, G. Der Zivilproze $\beta$ und neue Formen der Informationstechnik. In Zeitschrift für Zivilprozeß, No. 4, 2002.

KÖBLÖS, A. Hungary - Towards More Efficient Preparatory Proceeding. In ERVO, L., NYLUND, A. Current Trends in Preparatory Proceedings. Cham: Springer, 2016.

MOLNÁR, T. Az új polgári perrendtartás alapelveinek értékelése, a perjogi kodifikáció hatása a polgári eljárás sajátos alapelveire. In Közjegyzők Közlönye, No. 6 (2017).

VARGA, I. (ed.): A polgári perrendtartás és a kapcsolódó jogszabályok kommentárja. Budapest: HVG-ORAC, 2018.

VARGA, I. Identification of Civil Procedure Regulatory Needs with a Comparative View. In ELTE Law Journal, No. 6 (2014).

VARGA, I. Perrendi szabályozási igények azonosítása jogösszehasonlító kitekintéssel. In VARGA, I. (ed.): Codificatio processualis civilis. Studia in Honorem Németh János II. Budapest : ELTE Eötvös Kiadó, 2013.

\section{Contact information:}

prof. Dr. Viktória Harsági

harsagi.viktoria@jak.ppke.hu

Pázmány Péter Catholic University

Szentkirályi 28.

1088

Budapest

Hungary 